\title{
Changes in the Th1 : Th2 Cytokine Bias in Pregnancy and the Effects of the Anti-Inflammatory Cyclopentenone Prostaglandin 15-Deoxy- $\Delta^{12,14}$-Prostaglandin $\mathrm{J}_{2}$
}

\author{
Lynne Sykes, ${ }^{1}$ David A. MacIntyre, ${ }^{1}$ Xiao J. Yap, ${ }^{1}$ Sathana Ponnampalam, ${ }^{1}$ \\ Tiong Ghee Teoh, ${ }^{2}$ and Phillip R. Bennett ${ }^{1}$ \\ ${ }^{1}$ Parturition Research Group, Department of Surgery and Cancer, Institute of Reproduction and Developmental Biology, \\ Imperial College London, W120NN London, UK \\ ${ }^{2}$ St Mary's Hospital, Imperial College Healthcare NHS Trust, W21NY London, UK
}

Correspondence should be addressed to Phillip R. Bennett, p.bennett@imperial.ac.uk

Received 13 January 2012; Revised 6 March 2012; Accepted 2 April 2012

Academic Editor: Noboru Uchide

Copyright (C) 2012 Lynne Sykes et al. This is an open access article distributed under the Creative Commons Attribution License, which permits unrestricted use, distribution, and reproduction in any medium, provided the original work is properly cited.

\begin{abstract}
Pregnancy is a complex immunological state in which a bias towards T helper 2 (Th2) protects the fetus. Evidence suggests that proinflammatory cytokines increase the risk of poor neonatal outcome, independently of the direct effect of preterm labour. The anti-inflammatory prostaglandin 15 -deoxy- $\Delta^{12,14}$-Prostaglandin $\mathrm{J}_{2}\left(15 \mathrm{dPG}_{2}\right)$ inhibits nuclear factor Kappa B (NF- $\left.\kappa \mathrm{B}\right)$ in amniocytes and myocytes in vitro and is a ligand for the chemoattractant receptor-homologous molecule expressed on Th2 cells (CRTH2) receptor. Here we examine the Th1:Th2 cytokine bias in pregnancy and whether $15 \mathrm{dPGJ}_{2}$ could be used to inhibit the production of the proinflammatory cytokines through inhibition of NF- $\kappa$ B while simultaneously promoting Th2 interleukin 4 (IL-4) synthesis via CRTH2 in T helper cells. Peripheral blood mononuclear cells (PBMCs) from women at 28 weeks, term pre-labour, term labour as well as non-pregnant female controls were cultured with $15 \mathrm{dPGJ}_{2}$ or vehicle control and stimulated with phorbol myristyl acetate (PMA)/ionomycin. The percentage of CD4 $4^{+}$cells producing interferon gamma (IFN- $\gamma$ ) and tumor necrosis factor alpha (TNF- $\alpha$ ) in response to PMA/ionomycin was significantly reduced in pregnancy. $15 \mathrm{dPGJ}_{2}$ reduced IFN- $\gamma$ and TNF- $\alpha$ production in stimulated T helper cells, but did not alter IL-4 production in CRTH2 ${ }^{\text {+ve }}$ cells. $15 \mathrm{dPGJ}_{2}$ also reduced phospho-p65 in stimulated PBMCs. In summary, 15 $\mathrm{dPGJ}_{2}$ suppresses the Th1 response of PBMCs during pregnancy and active labour whilst maintaining the Th2 response suggesting a therapeutic benefit in reducing neonatal morbidity in inflammationinduced PTL.
\end{abstract}

\section{Introduction}

Preterm labour $<34$ weeks occurs in about $4 \%$ of pregnancies [1]. In $80-85 \%$ of cases of spontaneous preterm labour (PTL) $<28$ weeks, there is evidence of intrauterine infection [2]. Despite increased awareness of the association between inflammation and preterm labour [3], there have been no major advances in the prevention of preterm labour which have been shown to improve long-term neonatal outcomes. During normal term labour, the uterus and cervix become infiltrated with leukocytes and undergo changes in response to local secretion of proinflammatory cytokines. A similar pattern of biochemical events occur during PTL; however, the triggers for this premature activation are still not fully understood. Regardless, the presence of increased proinflammatory cytokines during pregnancy is clearly associated with a poor prognosis for babies born preterm [4].

The immune system can generally be divided into the innate and adaptive immune system. The former is a nonspecific system providing immediate defence against pathogens, while the latter is more targeted, characterised by $\mathrm{T}$ and $\mathrm{B}$ lymphocytes. Although cross-talk between these lymphocytes exist, B cells and their antibodies mainly give rise to humoral immunity, whereas $\mathrm{T}$ cells primarily provide cell mediated immunity [5]. T helper cells $\left(\mathrm{CD}^{+}\right)$form a subset of $\mathrm{T}$ cells and can be further subdivided into $\mathrm{T}$ helper 1 cells (Th1) and T helper 2 cells (Th2) depending on their pattern of cytokine production. Th1 cells secrete 
pro inflammatory cytokines such as interferon gamma (IFN$\gamma$ ) and tumor necrosis factor alpha (TNF- $\alpha)$, whereas the Th2 cells secrete anti-inflammatory cytokines such as interleukin 4 (IL-4), IL-10, and IL-13 [6]. A mutually exclusive interaction exists between the Th1 interleukin, IFN- $\gamma$, and the Th2 interleukin, IL-4. IL-4 is the dominant factor for promoting growth and differentiation from the Th0 to the Th2 subtype, and directly inhibits the development of the Th1 cells [7]. IFN- $\gamma$ indirectly promotes Th1 differentiation by upregulating the IL-12 receptor whilst inhibiting the growth of Th2 cells $[8,9]$.

Wegmann and colleagues first developed the concept that during pregnancy there is a shift from a $\mathrm{T}$ helper 1 (Th1) response to a T helper 2 (Th2) bias during pregnancy that functionally induces maternal tolerance and suppression [10]. Consistent with this notion, administration of the Th1 interleukins IFN- $\gamma$ [11] and IL-2 [12] leads to fetal loss and preterm labour in the mouse. Similarly, CBA $\times$ DBA/2 mice that have placentas deficient in IL-4 and IL-10 are prone to fetal resorption. Treatment of these mice via intraperitoneal injection of IL-10 protects the fetuses from resorption [13]. Several human studies have shown a Th2 bias in the ratio of circulating $\mathrm{T}$ helper cytokine profile in normal pregnancy; and an increase in the Th1 ratio in cases of recurrent miscarriage [14] and in preeclampsia [15]. Peripheral blood lymphocytes taken from women in the first trimester show an increased production of IL-4 and IL-10 and less IFN- $\gamma$ compared to nonpregnant controls in vitro [16]. There is in vivo evidence in pregnant women of increased expression of IL-4 messenger ribonucleic acid (mRNA) and lower expression of the IFN- $\gamma$ mRNA [17].

Not all studies support the requirement of the shift from Th1 to Th2 for successful pregnancy outcome $[18,19]$. Despite showing a suppression of IFN- $\gamma$ and an increase in IL-10 during pregnancy compared to nonpregnant controls, Bates et al. showed no difference in IFN- $\gamma$, IL-10, or IL-4 secretion in women who subsequently miscarried compared with those who went on to complete their pregnancy [18]. However, contrary to this study, women with recurrent miscarriage have been shown to have increased IFN- $\gamma$ and TNF- $\alpha$ levels compared with women that go on to have successful pregnancies [20]. While the mechanism regulating the Th1 : Th2 ratio is yet to be fully elucidated the importance of maternal immune tolerance during pregnancy is unquestionable. Several pregnancy-related proteins are known to promote Th2 bias such as leukemia inhibitory factor [21], progesterone, progesterone-induced blocking factor [22], and estradiol [23]. Prostaglandin $\mathrm{D}_{2}\left(\mathrm{PGD}_{2}\right)$ promotes IL-4, IL-13, IL-5, and IL-10 production in T helper 2 cells in vitro via the second $\mathrm{PGD}_{2}$ receptor; chemoattractant receptorhomologous molecule expressed on Th2 cells (CRTH2) [24]. $\mathrm{PGD}_{2}$ is produced by the placenta and may play a role in the chemoattraction of Th2 cells via the CRTH2 receptor to the maternal fetal interface to produce a localised Th2 bias [25].

15 -deoxy- $\Delta^{12,14}$-Prostaglandin $\mathrm{J}_{2}\left(15 \mathrm{dPGJ}_{2}\right)$, an endogenous prostaglandin $(P G)$, is a product of $\mathrm{PGD}_{2}$ via a series of dehydration reactions [26]. As well as being a ligand for Peroxisome proliferator-activated receptor gamma (PPAR $\gamma)$, it is also an agonist of the CRTH2 receptor [27]. We have previously demonstrated that this anti-inflammatory PG inhibits nuclear factor Kappa B (NF- $\kappa \mathrm{B})$ in amniocytes and myocytes in vitro [28] and delays infection induced preterm labour and increases pup survival in the mouse via NF- $\kappa \mathrm{B}$ inhibition [29]. Moreover, recent work has shown that the first trimester of pregnancy is associated with the suppression of available $\mathrm{T}$ cell $\mathrm{NF}-\kappa \mathrm{B}$ and reduced levels of IFN- $\gamma$ compared to nonpregnant controls [30, 31]. Collectively these data suggest that the Th1:Th2 ratio is modulated through the regulatory interplay of both Th1 suppression and Th2 promotion.

In this study, we examined the expression of the dominant Th1 interleukins IFN- $\gamma$ and TNF- $\alpha$, and the Th2 interleukin IL-4 in T helper cells obtained from nonpregnant women, women in the early and late third trimester, and during labour. We examined the effect of the CRTH2 agonist, $15 \mathrm{dPG}_{2}$, on these interleukins and on NF- $\kappa \mathrm{B}$ activation at different gestational time points to determine its potential role in suppressing the Th1 response via NF- $\kappa \mathrm{B}$ whilst simultaneously promoting the Th2 response via CRTH2.

\section{Materials and Methods}

2.1. Subjects. Pregnant women at 28 weeks and term (prelabour and in labour) and nonpregnant women of child bearing age were included in the study in accordance with ethical approval from the South East London Ethical Committee Ref. 10/H0805/54. Exclusion criteria included women with Asthma and HIV, women not of childbearing age, and women with a fever. After obtaining informed consent, $5 \mathrm{~mL}$ of peripheral venous blood was collected in sodium citrate tubes, and processed within 30 mins of collection. Unless otherwise stated, a minimum of 4 subjects were included for each experimental sample group.

\subsection{Isolation of Peripheral Blood Mononuclear Cells (PBMCs).} Blood was diluted 1:1 with phosphate-buffered saline (PBS) and carefully layered onto Ficoll-Paque PLUS (GE Healthcare, Uppsala, Sweden) before centrifuging at $400 \times \mathrm{g}$ for $40 \mathrm{mins}$ at room temperature. After centrifugation, the halo containing PBMCs was carefully transferred into a clean centrifuge tube and washed twice with $7 \mathrm{~mL}$ of PBS. After centrifugation $(400 \times \mathrm{g}$ for $10 \mathrm{mins})$, the cell pellet was resuspended in either PBS or RPMI 1640 (Invitrogen Life Technologies, Grand Island, NY, USA) culture medium.

2.3. CRTH2 Expression Studies. The PBMC pellet was resuspended PBS, and cells were counted with a Neubauer haemocytometer and then resuspended in staining buffer ( $1 \%$ fetal calf serum; $0.09 \%$ sodium azide in $\mathrm{PBS}$ ) to obtain roughly $3.5 \times 10^{6}$ cells per sample. Preparations were incubated in the dark for $1 \mathrm{~h}$ at $37^{\circ} \mathrm{C}$ with $20 \mu \mathrm{L}$ of CRTH2-phycoerythrin (CRTH2-PE) (Beckman Coulter, High Wycombe, UK) and $3 \mu \mathrm{L}$ of CD4-Allophycocyanin (CD4-APC) (BD Pharminogen, Oxford, UK) or the relevant isotype controls; Rat Immunoglobulin ( Ig) $\mathrm{G}_{2 \mathrm{a}}-\mathrm{PE}$ (Beckman Coulter) and Mouse $\operatorname{IgG}_{1 \kappa}$-APC (BD Pharminogen). After incubation, the PBMC suspension was washed twice in 
$1 \mathrm{~mL}$ of PBS and then resuspended in PBS for analysis. Flow cytometry settings were as follows: forward scatter E0 voltage, $1.00 \mathrm{Amp}$ gain Lin, and side scatter of 329 voltage, 1.00 Amp gain Lin. A total of 50,000 cells were counted and gating was on lymphocytes based on the forward and side scatter.

2.4. Intracellular Cytokine Studies (IL-4, IFN- $\gamma$, and TNF$\alpha$ ). For intracellular cytokine studies, cells were resuspended in RPMI 1640 (Invitrogen) media supplemented with 10\% fetal calf serum, $2 \mathrm{mM} / \mathrm{L}$ L-glutamine, $100 \mathrm{U} / \mathrm{mL}$ penicillin, and $100 \mu \mathrm{g} / \mathrm{mL}$ of streptomycin (Sigma, St. Louis, MO, USA) before being plated in 24-well plates and incubated for $18 \mathrm{~h}$ in $5 \% \mathrm{CO}_{2} /$ humidified air at $37^{\circ} \mathrm{C}$. Following this, $10 \mu \mathrm{g}$ of brefeldin A (Sigma) was added to each well to immobilize the interleukins in the golgi apparatus. Cells were pretreated with $32 \mu \mathrm{M}$ of $15 \mathrm{dPGJ}_{2}$ (Cayman Chemicals, Ann Arbor, MI, USA) or dimethyl sulfoxide (DMSO) (Sigma) vehicle control for $2 \mathrm{~h}$ in the case of IFN- $\gamma$ and TNF- $\alpha$ experiments or $1 \mathrm{~h}$ for IL-4. Following this $50 \mathrm{ng} / \mathrm{mL}$ of phorbol myristate acetate (PMA) and $0.5 \mu \mathrm{g} / \mathrm{mL}$ of ionomycin were added for $4 \mathrm{~h}$ in the case of IFN- $\gamma$ and TNF- $\alpha$ experiments or $5 \mathrm{~h}$ for IL-4. Prior to intracellular staining, cell surface staining with either CRTH2 and CD4, or CD4 antibodies alone, was performed as described in Section 2.3. Cells were then fixed with $2 \%$ paraformaldehyde (PFA) and incubated at $37^{\circ} \mathrm{C}$ for $15 \mathrm{mins}$ in the dark. Cells were washed and resuspended in $0.5 \%$ saponin and incubated for 30 mins on ice in the dark to permeabilize the cells. After incubation, cells were washed and resuspended in $0.5 \%$ saponin for intracellular staining with the relevant antibody; IL-4 PE/Cy7 (BioLegend, San Diego, CA, USA), IFN- $\gamma$-(fluorescein isothiocyanate (FITC) or TNF- $\alpha$-FITC (BD Biosciences, Franklin Lakes, NJ, USA). Appropriate isotype controls were used; $\mathrm{PE} / \mathrm{Cy} 7 \mathrm{Rat} \mathrm{IgG}_{1 \kappa}$ (Biolegend), or FITC Mouse IgG $\mathrm{I}_{1 \kappa}$ (BD Biosciences, Oxford, $\mathrm{UK})$. Cells were incubated in the dark for $1 \mathrm{~h}$ at room temperature for IL-4 staining or 20 mins on ice for IFN- $y$ and TNF- $\alpha$ staining. Finally, cell suspensions were washed with $0.5 \%$ saponin and resuspended in PBS for flow cytometry analysis as follows: Forward scatter E0 voltage; 1.00 Amp gain Lin; side scatter of 329 Voltage; 1.00 Amp gain Lin.

2.5. Flow Cytometry. Flow cytometry of lymphocytes was carried out using FACSCalibur flow cytometer (BD Biosciences) equipped with FACSCalibur software for analysis. The lymphocyte population was gated on the scatter plot as determined by the characteristic forward scatter (FS) and side scatter (SC) which indicates the cell size and shape. The analysis was of $\mathrm{CD}_{4}^{+}, \mathrm{CRTH}_{2}{ }^{+}$, and $\mathrm{CRTH} 2^{+} / \mathrm{CD}^{+}$in the CRTH2 expression studies and IL- $4^{+}, \mathrm{IL}^{+} 4^{+} / \mathrm{CRTH} 2^{+}$, TNF$\alpha^{+} / \mathrm{CD}^{+}$, and IFN- $\gamma^{+} / \mathrm{CD} 4^{+}$for the intracellular cytokines. The expression levels of CRTH2, CD4, and intracellular cytokines were evaluated by the percentage of cells expressing the protein of interest or by mean fluorescence intensity (MFI).

2.6. Sodium Dodecyl Sulfate Polyacrylamide Gel Electrophoresis (SDS-PAGE) and Western Blotting. Following culture and treatments, cells were collected using a $1 \mathrm{~mL}$ pipette and incubated on ice in whole cell lysis buffer (Cell Signalling, Beverly, MA, USA) with $5 \mu \mathrm{L} / \mathrm{mL}$ of protease inhibitor (Sigma) lysis buffer for 5 mins and centrifuged for 20 mins at $13,000 \mathrm{rpm}$ at $4^{\circ} \mathrm{C}$. The supernatant was stored at $-80^{\circ} \mathrm{C}$ until use. Prior to SDS-PAGE, protein concentrations were determined using the BIORAD quantification assay measuring absorbance at $655 \mathrm{~nm}$. Approximately $15 \mu \mathrm{g}$ of extracted protein per sample was resolved by SDS-PAGE and subsequently transferred onto polyvinyl difluoride (PVDF) membranes (GE Healthcare) $100 \mathrm{~V}$ constant at $4^{\circ} \mathrm{C}$. Following transfer, the membrane was then blocked in 5\% (wt/vol) milk in tris-buffered saline (TBS) supplemented with $0.1 \%$ Tween 20 (TBST) for $1 \mathrm{~h}$. The membrane was then probed with phospho-p65 (Ser 536) (Cell signalling) primary antibody ( $1: 1000$ in tris-buffered saline) overnight at $4^{\circ} \mathrm{C}$ followed by the appropriate secondary antibody $(1: 2000$ in $1 \%$ milk/TBS) for $1 \mathrm{~h}$ at room temperature. Chemiluminescence detection was then carried out with ECL Plus (GE Healthcare), and the membranes developed using a high-performance chemiluminescence film (GE Healthcare). Blots were scanned, and densitometry was performed with ImageJ (v1.44p).

2.7. Statistical Analysis. Experimental sample groups consisted of at least 4 biological replicates unless otherwise stated. Statistical analysis was performed with Graph-Pad Prism (v4.0; GraphPad Software, San Diego, CA, USA). Paired Student's $t$-test or repeated measures ANOVA was conducted where appropriate. Samples with $P<0.05$ was considered to be statistically significant.

\section{Results}

3.1. Gestational Effect on Th1 and Th2 Cytokines. A change in the production of the Th1 and Th2 cytokines in pregnancy has previously been described. In this study, we employed flow cytometry to examine the effect of stimulation by the mitogen PMA/ionomycin on cytokine production at different gestational stages of pregnancy and during labour (see Figure 1). Th1 cytokine profiles of CD4 positive cells were assessed for intracellular IFN- $\gamma$ and TNF- $\alpha$ (Figures $1(\mathrm{a})-1(\mathrm{~d}))$ and compared to levels of nonpregnant controls. The percentage of peripheral T cells producing IFN- $\gamma$ in response to stimulation reduced in pregnancy from $10.7 \%$ in nonpregnant women to $6.7 \%$ at 28 weeks, $5.1 \%$ at term $(P<0.05)$, and $5.6 \%$ at term in labour $(P<$ $0.05)$. Similarly, the proportion of TNF- $\alpha$ producing cells was reduced, although not significantly, from $20.6 \%$ in nonpregnant women to $14.5 \%$ at 28 weeks, $15.8 \%$ at term and $13.3 \%$ at term in labour. Overall levels of Th1 cytokine production (expressed as mean fluorescence intensity), in the $\mathrm{CD} 4^{+} / \mathrm{IFN}-\gamma^{+}$or $\mathrm{CD} 4^{+} / \mathrm{TNF}-\alpha^{+}$cells remained consistent throughout gestation and unchanged compared to nonpregnant controls. The Th2 cytokine, IL-4, was similarly assessed in CRTH2 positive cells (Figures $1(\mathrm{e})$ and $1(\mathrm{f})$ ). While PMA/ionomycin stimulation did not increase the percentage of IL-4 expressing cells, the mean fluorescence intensity of 


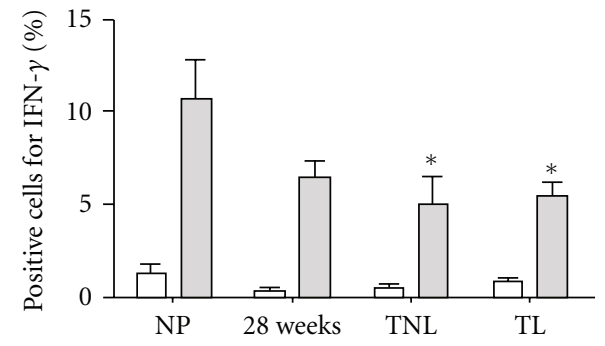

(a)

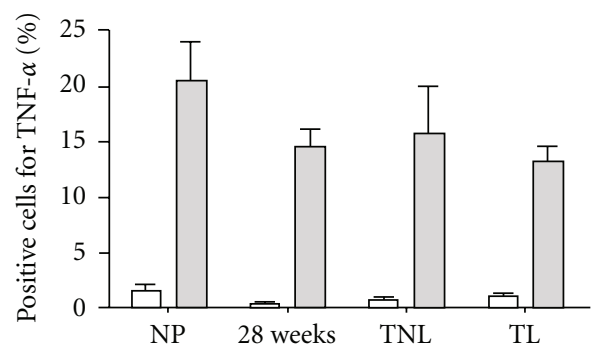

(c)

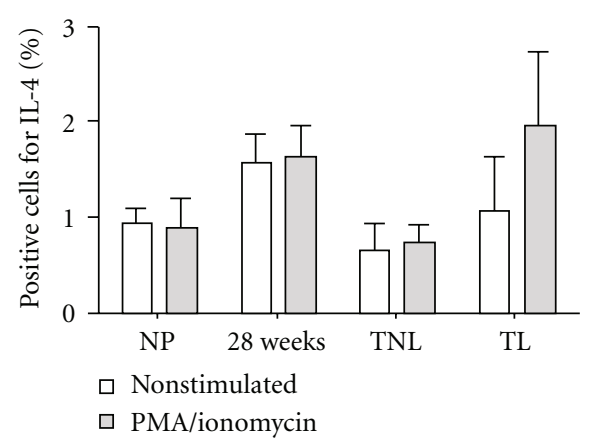

(e)

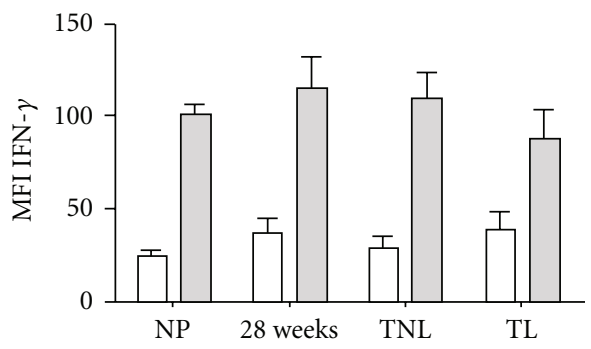

(b)

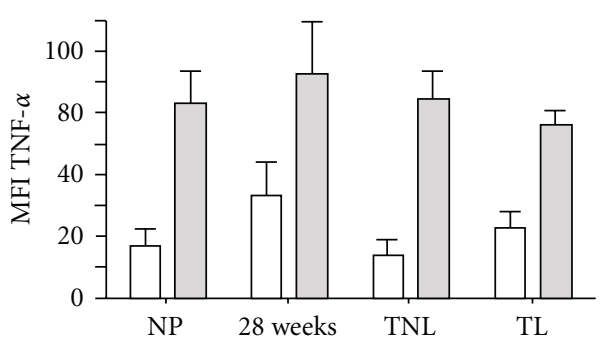

(d)

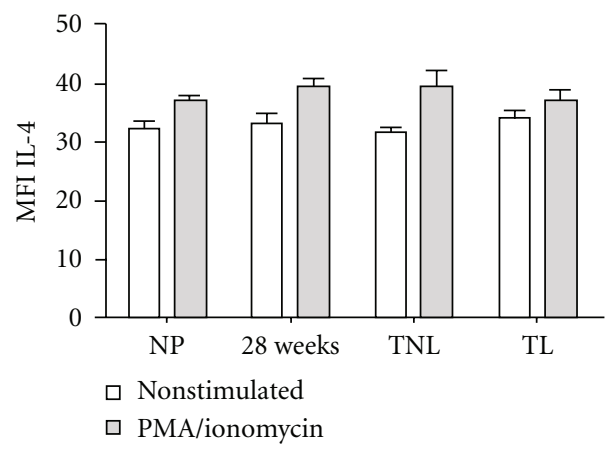

(f)

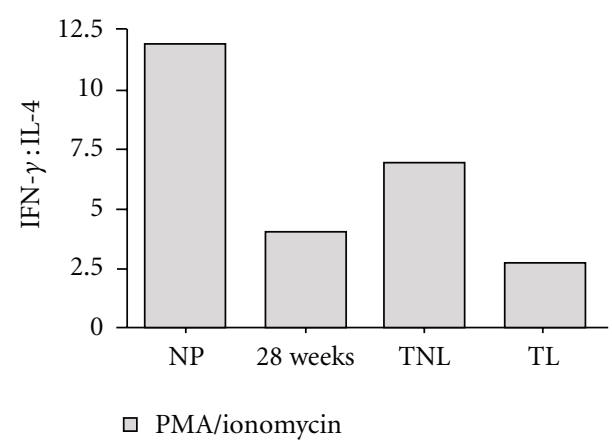

(g)

FIGURE 1: Th1 and Th2 cytokine production in peripheral T cells from nonpregnant and pregnant women. Peripheral blood mononuclear cells were isolated and stimulated with PMA/ionomycin. The percentage of CD4 $4^{+} / \mathrm{IFN}-\gamma^{+}, \mathrm{CD} 4^{+} / \mathrm{TNF}-\alpha^{+}$, and CRTH2 $/ \mathrm{IL}-4$ positive cells were detected by flow cytometry in samples derived from nonpregnant (NP), 28-week pregnant, term no labour (TNL), and term labour (TL) samples (a), (c), and (e). A reduction in the percentage of peripheral CD4 positive cells secreting the Th1 cytokines IFN- $\gamma$ and TNF- $\alpha$ was observed, whereas the percentage of cells secreting the Th2 cytokine, IL-4, remained consistent throughout gestation. Mean fluorescence intensity (MFI) was also assessed as a measure of total cytokine production (b), (d), and (f). PMA/ionomycin stimulation induced both Th1 and Th2 cytokine production in all sample groups compared to NL controls. No differences in gestation-dependent responses were detected. (g) a ratio of IFN- $\gamma$ : IL-4 revealed a decrease in the Th1: Th2 ratio during pregnancy, which was increased prior to the onset of labour. For statistical analysis ANOVA with Dunnett's multiple comparison test with NP as a control was used; ${ }^{* *} P<0.01$ and ${ }^{*} P<0.05$. 


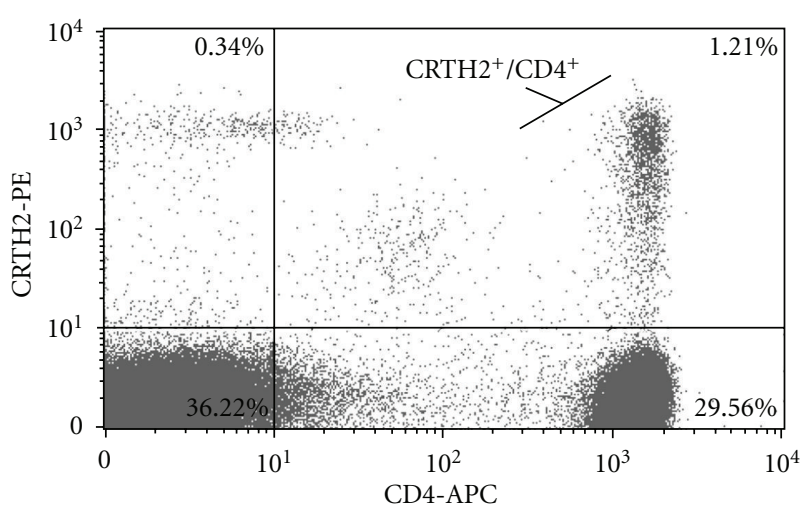

(a)

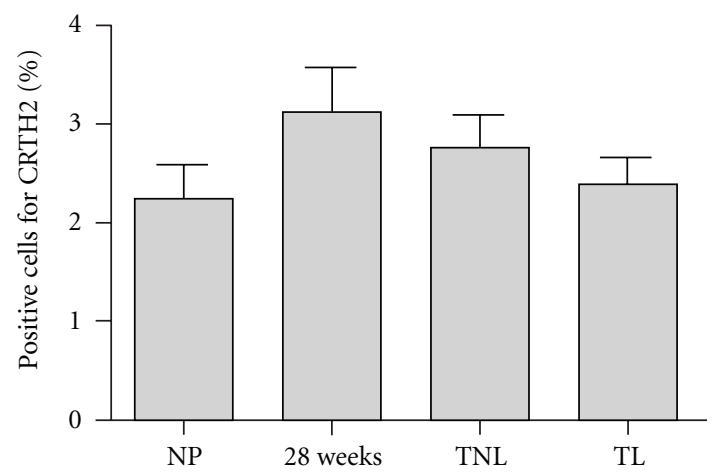

(b)

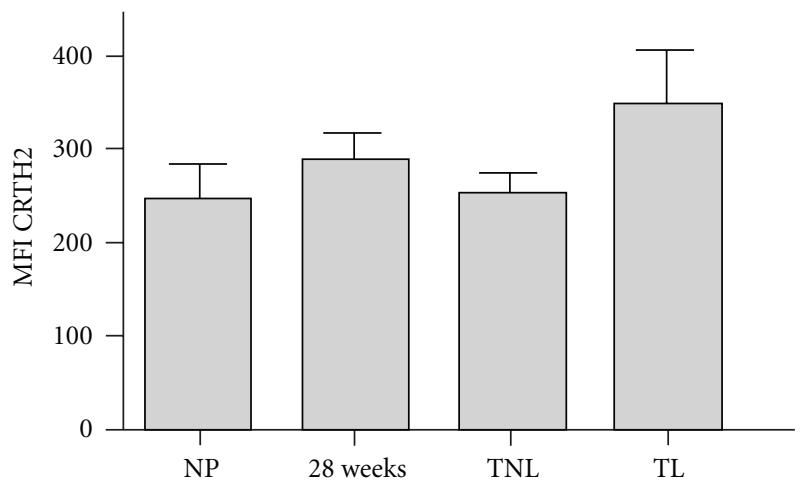

(c)

FIGURE 2: CRTH2 expression in lymphocytes derived from nonpregnant and pregnant subjects. Lymphocytes were gated according to forward scatter and side scatter and T helper cells were identified using CD4 as a cell surface marker $(n=8$ for each group). A representative cytogram from a woman of 28 -week gestation is presented with the right upper quadrant showing $\mathrm{CRTH} 2^{+} / \mathrm{CD} 4^{+}$lymphocytes $(\mathrm{a})$. The percentage of CRTH2 positive T helper cells (presented as a percentage of positive CD4 positive cells) increased slightly in the third trimester, although statistical significance was not reached (b). No change in mean fluorescence intensity was detected in either the nonpregnant or pregnant samples (c). For statistical analysis ANOVA with Dunnett's multiple comparison test with NP as a control was used.

IL-4 was significantly increased in samples collected from women at 28 weeks $(39.3, P<0.01)$ and at term $(39.4$, $P<0.05)$ compared to levels of nonpregnant controls $(37.1)$. Levels of IL-4 in term labouring samples were consistent with nonlabouring samples (37.1). The ratio of the IFN$\gamma$ : IL-4 producing cells reduces during pregnancy, due to the suppression of the Th1 rather than the promotion of the Th2 cytokine production (Figure $1(\mathrm{~g})$ ).

3.2. CRTH2 Expression. To determine whether the Th2 response in pregnancy is reflected by an increase in the percentage of CRTH2 positive cells, we used CD4 as a marker of $\mathrm{T}$ helper cells and calculated the percentage these cells that express CRTH2 (Figure 2(a)). The percentage of CRTH2 positive cells in the CD4 positive population was observed to increase in the second trimester of pregnancy from $2.24 \%$ in nonpregnant women to $3.12 \%$ at 28 weeks before reducing to $2.75 \%$ at term and $2.4 \%$ in term labour, although statistical significance was not reached (Figure 2(b)). There was no significant increase in the mean fluorescence intensity of CRTH2 in T helper cells between nonpregnant and pregnant subjects (Figure 2(c)), although a slight increase in CRTH2 production was noted in term labouring samples $(P=0.15)$.

3.3. The Effect of $15 d P G J_{2}$ on the Th1 and Th2 Cytokines. $15 \mathrm{dPG}_{2}$ is an anti-inflammatory $\mathrm{PG}$ and a ligand for CRTH2. We therefore explored the effect of $15 \mathrm{dPGJ}_{2}$ on the Th1 cytokines, IFN- $\gamma$ and TNF- $\alpha$. To do this, cells were preincubated with $32 \mu \mathrm{M}$ of $15 \mathrm{dPGJ}_{2}$ or vehicle control prior to the addition of PMA/ionomycin before intracellular cytokines were detected by flow cytometry (Figures 3(a) and $3(\mathrm{~b})) .15 \mathrm{dPG}_{2}$ reduced the production of PMA/ionomycin stimulated IFN- $\gamma$ production (measured as mean fluorescence intensity) in T helper cells from 101.9 to $53(P<$ $0.01)$ in nonpregnant controls, 115.7 to $52.4(P<0.01)$ in 28 week samples and from 110 to 60.7 in term $(P<$ 0.01 ) samples. There was a nonsignificant decrease observed in term labouring samples also (88.3 to 66.3, Figure 3(c)). Similarly, a significant decrease in PMA/ionomycin-induced TNF- $\alpha$ production following treatment with $15 \mathrm{dPGJ}_{2}$ was detected in all pregnant samples assessed (Figure 3(d)).

The percentage of $\mathrm{T}$ helper cells producing IFN- $\gamma$ was also reduced from $10.7 \%$ to $5.13 \%$ in nonpregnant women 

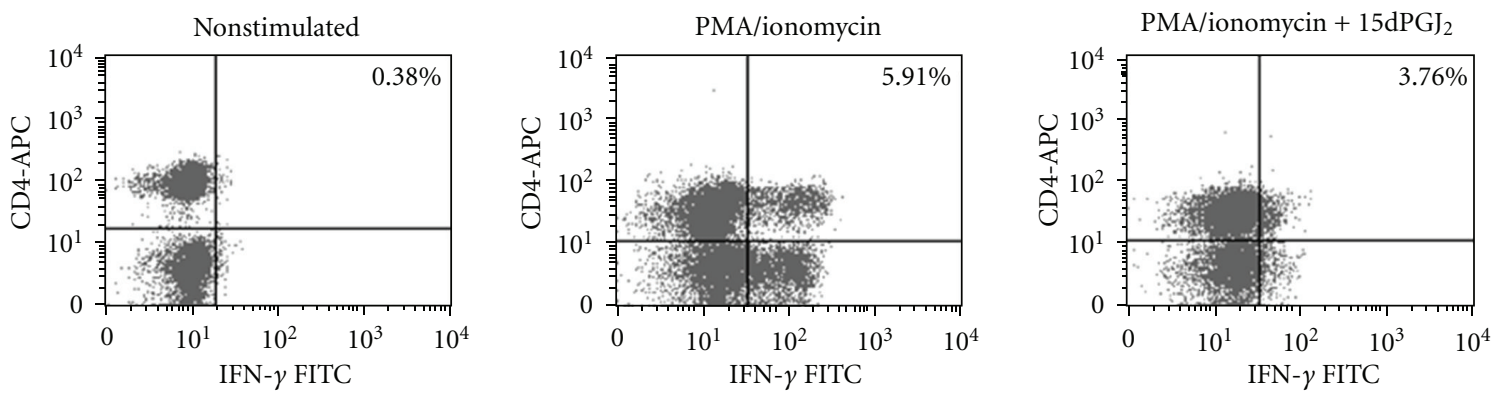

(a)

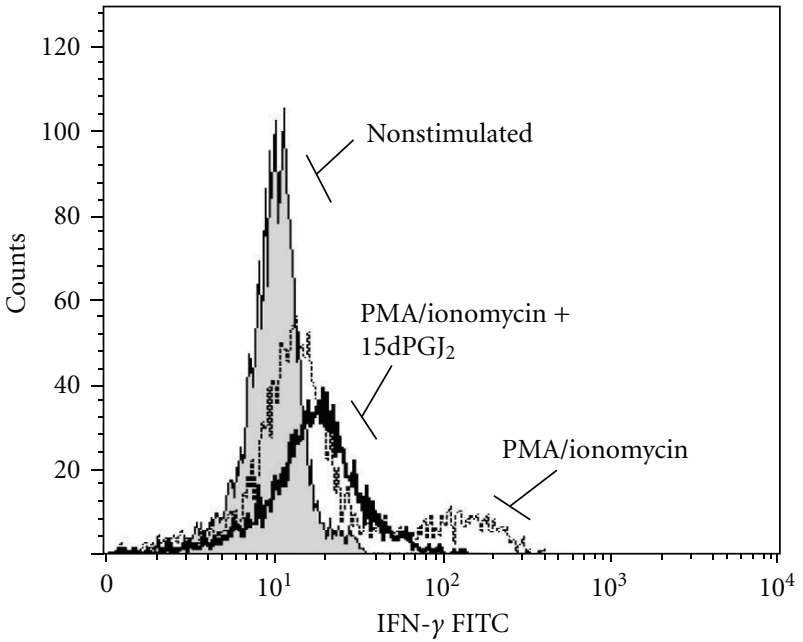

(b)

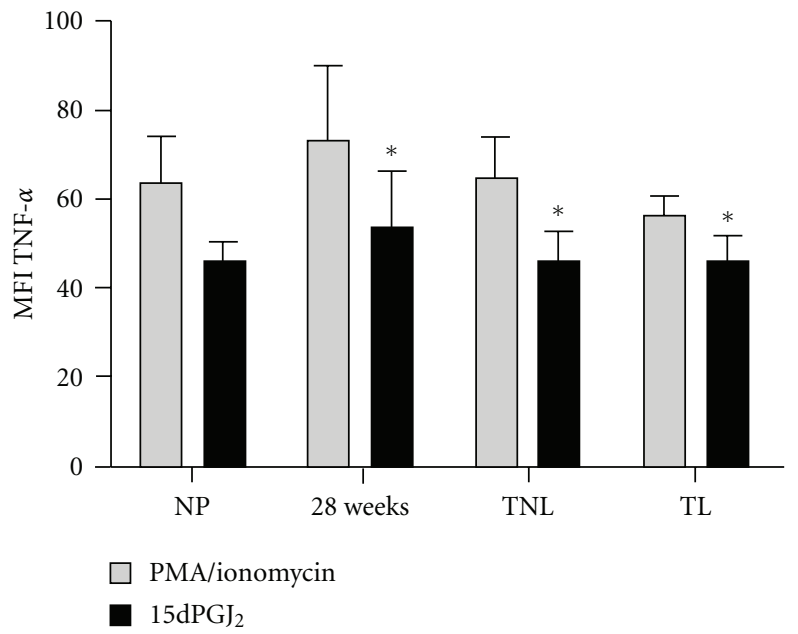

(d)

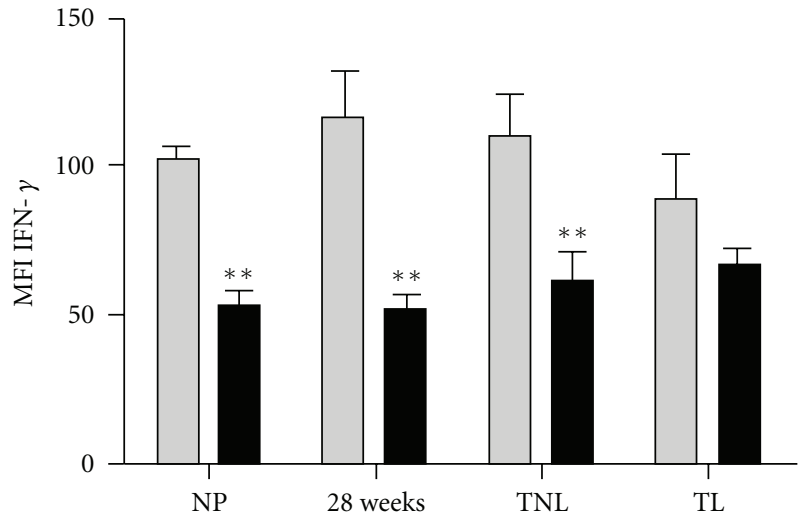

$\square$ PMA/ionomycin

- $15 \mathrm{dPGJ}_{2}$

(c)

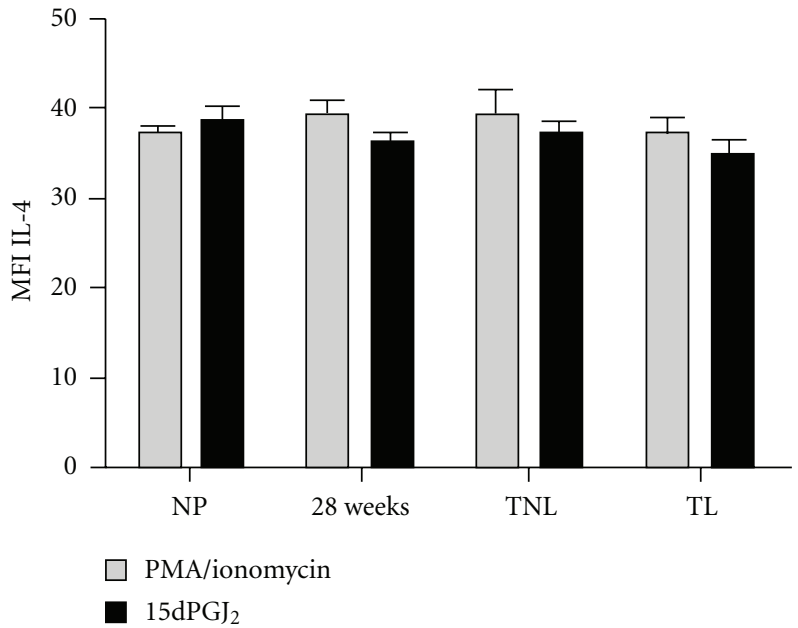

(e)

Figure 3: Effect of 15dPGJ2 on Th1 and Th2 cytokines. Peripheral blood mononuclear cells were incubated with vehicle control or $32 \mu \mathrm{M}$ of $15 \mathrm{dPGJ}_{2}$ and stimulated with PMA/ionomycin before being gated on the lymphocyte population according to forward and side scatter. A representative 28 -week patient sample is presented with $\mathrm{CD} 4^{+} / \mathrm{IFN}-\gamma^{+}$cells shown in the right upper quadrant (a). A representative histogram reveals a clear shift to the right upon stimulation indicative of increased IFN- $\gamma$ producing cells (b). This effect was attenuated with $15 \mathrm{dPG}_{2}$ pre-treatment. PMA/ionomycin induced IFN- $\gamma$ and TNF- $\alpha$ production was decreased with $15 \mathrm{dPGJ}_{2}$ treatment (c) and (d); however, levels of IL-4 remained unchanged. No change in IL-4 producing cells was detected (e). For statistical analysis a Student's $t$-test was used to compare means between paired treated and nontreated samples; ${ }^{*} P<0.01$ and ${ }^{*} P<0.05$. 
$(P<0.01), 6.6 \%$ to $3.4 \%$ at 28 weeks $(P<0.01), 5.1 \%$ to $2.5 \%$ at term $(P<0.05)$, and $5.6 \%$ to $2.9 \%(P<0.01)$. A reduction in the percentage of T cells producing TNF- $\alpha$ was also seen with $15 \mathrm{dPGJ}_{2}$ from $20.6 \%$ to $16.7 \%$ in nonpregnant women, $14.5 \%$ to $9.0 \%$ at 28 weeks $(P<0.05), 15.8 \%$ to $12.9 \%$ at term $(P<0.01)$, and $13.2 \%$ to $8.93 \%$ at term in labour $(P=0.05)$ (data not shown).

Considering its anti-inflammatory properties, it was hypothesized that $15 \mathrm{dPGJ}_{2}$ would induce an increase in IL-4 production via its action on the CRTH2 receptor. Contrary to what was anticipated, $15 \mathrm{dPGJ}_{2}$ had no effect on the production of IL-4 (Figure 3(e)). Consistent with this, the percentage of CRTH2+/IL-4+ lymphocytes remained constant following $15 \mathrm{dPGJ}_{2}$ treatment except for samples collected at 28 weeks gestation $(1.65 \%$ to $1.16 \%, P<0.05$; data not shown).

3.4. $15 \mathrm{dPGJ}_{2}$ Inhibits PMA/Ionomycin-Stimulated $N F-\kappa B$ Activation in Peripheral Blood Mononuclear Cells. Peripheral blood mononuclear cells were incubated with vehicle control or $32 \mu \mathrm{M} 15 \mathrm{dPGJ}_{2}$ and stimulated with PMA/ionomycin for $10 \mathrm{~min}$ before being extracted and assessed for levels of phosphorylated p65, the transcriptionally active subunit of NF- $\kappa$ B. PMA/ionomycin treatment stimulated NF- $\kappa$ B phosphorylation in all samples and at all gestational time points (Figure 4). Pretreatment of cells with $15 \mathrm{dPGJ}_{2}$ significantly reduced levels of p-p65 in samples collected from women at 28-week gestation. A clear trend of decreased p-p65 following $15 \mathrm{dPGJ}_{2}$ was observed in the remaining samples yet they did not return to basal levels of p-p65.

\section{Discussion}

The immunological paradox of pregnancy relies on a careful balance of both immune tolerance and immune suppression. Work by Medawar, and later Wegmann and colleagues, has led to the proposal that this balance is determined by a functional immune suppression via a shift from a Th1 response to a Th2 bias during pregnancy $[10,20,32]$. Although not all human and murine studies support the importance or the simplification of the Th1 : Th2 paradigm $[18,19,33]$, further understanding of this hypothesis to aid the development of new therapeutic strategies is still required. In this study, we have explored the Th1 cytokines IFN- $\gamma$ and TNF- $\alpha$, and the Th2 cytokine IL- 4 throughout pregnancy, and examined the potential of the cyclopentenone PG CRTH2 agonist, $15 \mathrm{dPGJ}_{2}$, to act as a therapeutic agent to modulate the Th1 : Th2 response.

Consistent with the notion of suppressed Th1 cytokine response throughout gestation $[16,17,34,35]$, our results revealed a reduction in the percentage of IFN- $\gamma$ and TNF$\alpha$-secreting $\mathrm{T}$ helper cells during pregnancy in response to PMA/ionomycin stimulation (Figures $1(\mathrm{a})$ and $1(\mathrm{c})$ ). However, mean production of IFN $-\gamma$ and TNF- $\alpha$ remained constant within the $\mathrm{CD} 4^{+} / \mathrm{IFN}-\gamma^{+}$and $\mathrm{CD} 4^{+} / \mathrm{TNF}-\alpha^{+}$cell populations (Figures $1(\mathrm{~b})$ and $1(\mathrm{~d})$ ). This indicates that while fewer cells maintain the capacity to initiate a Th1 response to inflammatory stimuli with advancing gestation, a compensatory mechanism facilitates increased IFN- $\gamma$ and TNF- $\alpha$ production. These results suggest that Th1 response during gestation is likely to be regulated at both an individual cellular level as well as at the level of the cell population.

As normal human labour reflects a proinflammatory state, we anticipated that the percentage of IFN- $\gamma$ and TNF$\alpha$ producing $\mathrm{T}$ helper cells would increase with the onset of labour. However, no difference between term nonlabouring and term labouring samples was detected. This may be due to the proinflammatory state of labour being a localized response in the uterus and fetal membranes, rather than an extending to peripheral inflammation. This would be consistent with the localised increase in the DNA binding activity of NF- $\kappa \mathrm{B}$ in amnion cells postlabour compared to prelabour [36] and in myometrium during labour compared to pre-labour [37] as well as the reported increase in labour of IFN- $\gamma$ in amnion, choriodecidua, and placenta [38], and TNF- $\alpha$ in the amniotic fluid, myometrium, and cervix [39, 40] rather than in the peripheral blood.

A number of studies have shown that mitogen stimulation can induce IL-4 production in PBMCs of the second and third trimesters of pregnancy in vitro $[16,35,41]$. Intrinsic IL-4 production by PBMCs also shows an increase in pregnancy compared with nonpregnant controls [17, 42]. We therefore hypothesized that PMA/ionomycin stimulation of PMBCs would drive IL-4 production during pregnancy, and that this phenomenon would subside at term concurrent with the activation of inflammatory pathways involved in normal labour pathways. To examine any evidence of a shift towards the Th2 profile in peripheral blood during pregnancy, PBMCs were gated for CRTH2 (a marker for Th2 cells) and the level of IL-4 assessed (Figures 1(e) and $1(\mathrm{f}))$. The percentage of $\mathrm{CRTH} 2^{+} / \mathrm{IL}-4^{+}$secreting cells, as well as mean production levels of IL-4 remained consistent throughout pregnancy and advancing gestation (Figures 1(f) and $1(\mathrm{e})$ ) although a slight increase in the percentage of IL4 secreting cells was observed in both nonstimulated and stimulated 28 -week samples. Between $0.4-6.5 \%$ of peripheral blood $\mathrm{CD}^{+}$cells of nonpregnant women express CRTH2 and secrete IL-4, but not IFN- $\gamma$, in response to PMA and ionomycin and are thus typical of Th2 cells [43]. Consistent with this, we found that between $2-4 \%$ of $\mathrm{CD}^{+}$ PMBCs express CRTH2 (Figure 2(a)). This percentage was maintained throughout gestation with a minor, statistically nonsignificant, increase observed at 28 weeks (Figure 2(b)). Tsuda et al. have previously reported an increase in CRTH2 expression in $\mathrm{CD}^{+}$cells between nonpregnant $(2.08 \%)$ and 7 -week gestation $(3.43 \%, P=0.02)$ [44], but it is possible that this effect is diminished with advancing gestation. Mean levels of CRTH2 expressed in $\mathrm{CD}^{+}$cells were also unchanged through gestation and labour (Figure 2(c)). Taken together with the fact that we were unable to detect any difference in IL-4 secretion levels in these cells upon mitogen stimulation, our results collectively suggest that the Th2 response in PMBCs is maximised during pregnancy and cannot be further stimulated. This would imply that any beneficial effects of therapeutic agents intended to push the Th2: Th1 ratio towards Th2 would need to do so through inhibition of Th1, rather than upregulation of Th2. Although 


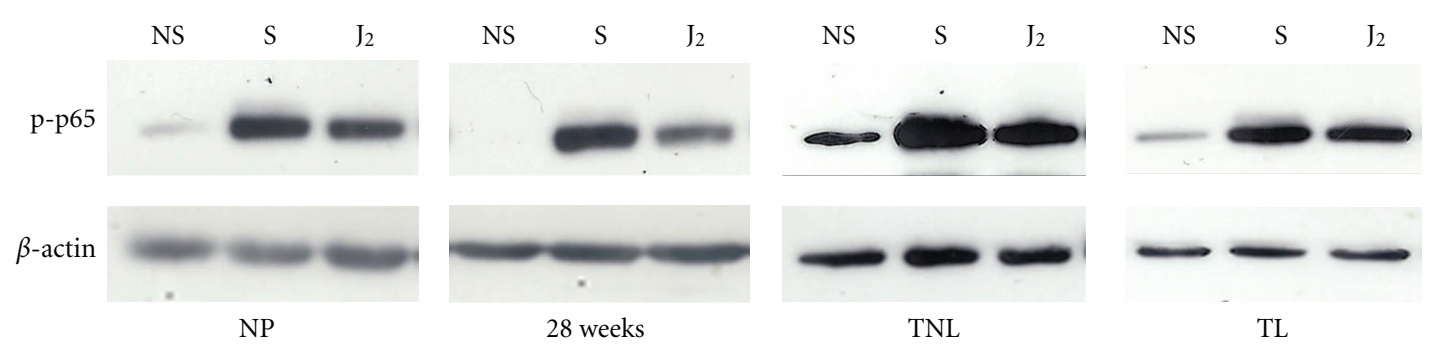

(a)

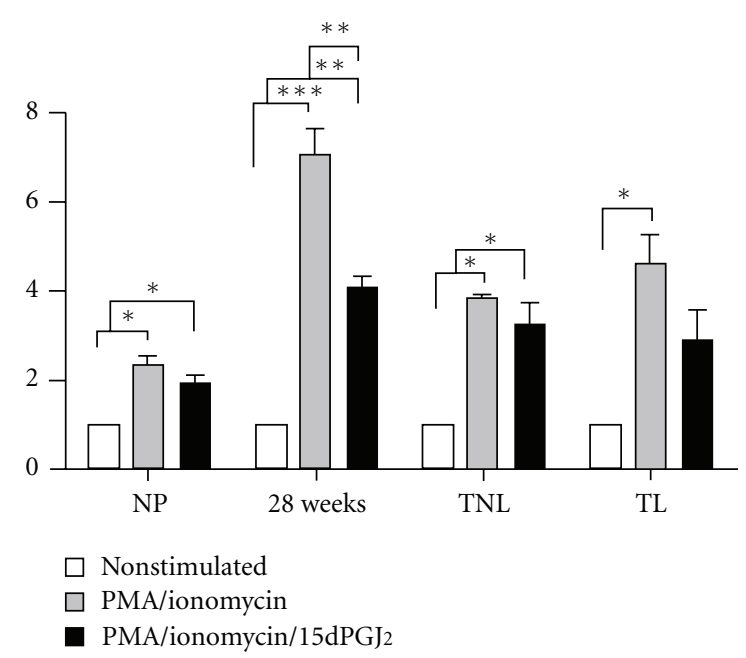

(b)

FIGURE 4: The effect of 15dPGJ2 on NF- $\kappa$ B p65 phosphorylation in peripheral blood mononuclear cells. PBMCs were treated as previously described before being extracted and levels of phosphorylated p65 (p-p65) examined using immunoblotting. Representative immunoblots are shown for each gestational time point (a). Immunoblots were reprobed for $\beta$-actin as an internal loading control. Densitometric analysis of the immunoblots was conducted revealing a significant increase in p-p65 levels upon stimulation with PMA/ionomycin in all samples (b). A significant decrease in PMA/ionomycin stimulated p-p65 was observed following $15 \mathrm{dPGJ}_{2}$ treatment in 28 -week samples. The capacity of $15 \mathrm{dPGJ}_{2}$ to inhibit PMA/ionomycin-induced p-p65 was lost in those samples collected at term. NS: nonstimulated, S: PMA/ionomycin stimulated, and $\mathrm{J}_{2}: 15 \mathrm{dPGJ}_{2}$ pretreatment. Effect of treatment was examined for statistical significance at each gestational timepoint using ANOVA with Bonferroni's multiple comparison test; ${ }^{* * *} P<0.001, * * P<0.01$ and ${ }^{*} P<0.05$.

the percentage of $\mathrm{CRTH} 2$ expressing $\mathrm{CD}^{+}$cells is low in the peripheral blood, we are unable to rule out any modest yet biologically significant changes in IL-4 production from these cells at a tissue-specific level.

To further investigate the potential of Th2 promotion versus Th1 suppression, we examined the response of PBMCs to $15 \mathrm{dPGJ}_{2}$, an endogenous product of Prostaglandin $\mathrm{D}_{2}$ $\left(\mathrm{PGD}_{2}\right)$ (and potential therapeutic agent) that has been shown to promote Th2 bias through IL-4 production in $\mathrm{T}$ helper 2 cells in vitro via CRTH2 [24]. $\mathrm{PGD}_{2}$ is readily converted to $15 \mathrm{dPGJ}_{2}$ by a series of dehydration reactions in the presence of albumin and is found in the amniotic fluid [45], placenta [46], and urine [47]. $15 \mathrm{dPGJ}_{2}$ pretreatment significantly inhibited the PMA-stimulated production of both Th1 cytokines: IFN- $\gamma$ and TNF- $\alpha$, in nonpregnant and all pregnant samples (Figures $3(\mathrm{a})-3(\mathrm{~d})$ ). However, no effect on the production of the Th2 cytokine, IL-4, could be detected in response to $15 \mathrm{dPGJ}_{2}$ treatment. This may be due to an overriding effect of a non-CRTH2mediated mechanism such as the inhibition of other signalling proteins involved the transcriptional regulation of
IL-4 expression. Evidence for this has been previously reported in a PMA/Ionomycin-activated T-cell line, where $15 \mathrm{dPGJ}_{2}$ inhibited IL-4 production in a dose-dependent manner through the downregulation of nuclear factor of activated T-cells (NF-AT) activation [48].

The anti-inflammatory properties of $15 \mathrm{dPGJ}_{2}$ are thought to be at least partly via the inhibition of the transcription factor NF- $\kappa$ B [49]. NF- $\kappa$ B is known to play a key regulatory role in controlling the Th1 immune response by modulating the expression of Th1 cytokines [31]. NF- $\kappa \mathrm{B}$ activity in PBMCs during pregnancy is reduced compared to nonpregnant controls [50], and it has therefore been suggested that this is responsible for suppressed Th1 response in pregnancy [30]. To determine whether the observed inhibitory effects of $15 \mathrm{dPGJ}_{2}$ on Th1 cytokine production may be via NF- $\kappa \mathrm{B}$, treated cells were extracted, and levels of the transcriptionally active NF- $\kappa \mathrm{B}$ subunit $\mathrm{p}$-p65 were examined by immunoblotting. Our results indicate that $15 \mathrm{dPGJ}_{2}$ significantly inhibits p-p65 in PMA/ionomycin stimulated Thelper at 28 weeks of gestation. A nonsignificant reduction was also observed in nonpregnant controls and 


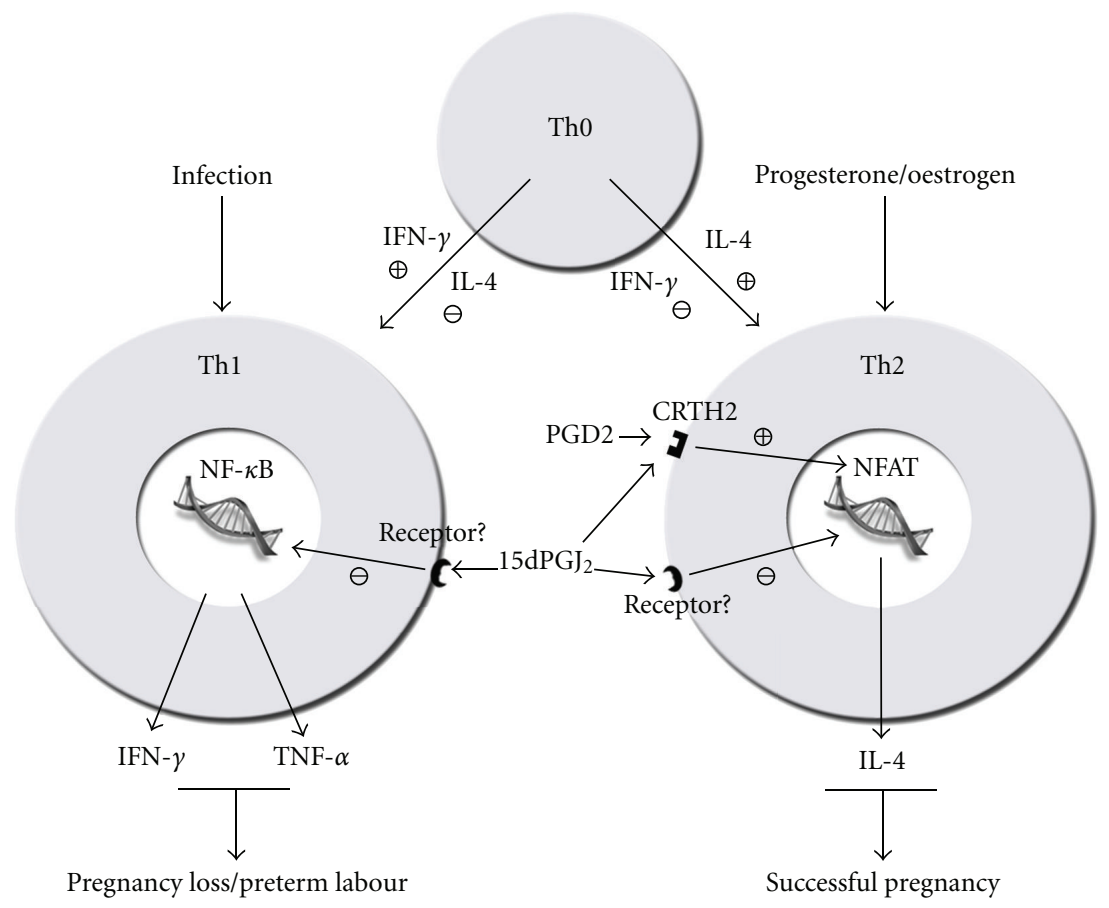

FIGURE 5: Schematic proposal of the Th1 and Th2 balance and the role of CRTH2 and NF- $\kappa$ B. T-helper cell precursors are directed toward committed immunophenotype by the typical Th1 and Th2 interleukins, IFN- $\gamma$ and IL-4, respectively. Infection or propregnancy hormones such as progesterone can further modulate the Th1/Th2 bias. Based upon our findings and those of others, we propose that $15 \mathrm{dPGJ}$ maintains a Th2 bias principally through the suppression Th1 interleukins through the inhibition of NF- $\kappa$ B.

samples acquired at term. This data provides evidence that the Th1 inhibitory properties of $15 \mathrm{dPGJ}_{2}$ are likely regulated through NF- $\kappa$ B.

$15 \mathrm{dPGJ}_{2}$ is a cyclopentenone PG which possesses an $\alpha, \beta$ unsaturated carbonyl group in the cyclopentenone ring [51]. This group can form Michael adducts with I Kappa B kinase (IKK) [52], and the p65 [53] and p50 subunits leading to modification of these proteins, thus inhibition of NF- $\kappa$ B activity [51]. We have shown that in amnion and myometrial cells, inhibition of NF- $\kappa$ B by $15 \mathrm{dPGJ}_{2}$ is not via PPAR- $\gamma$ [28]. However, $15 \mathrm{dPGJ}_{2}$-mediated suppression of Th1 interleukin expression in lymphocytes via PPAR- $\gamma$ receptor inhibition or activator protein 1 (AP-1) has not been ruled out in this study.

While $15 \mathrm{dPGJ}_{2}$ appears to have no effect on the peripheral Th2 response, the demonstrated inhibition of the Th1 response represents a collective shift toward a Th2 bias, or in other words, an increase in the Th2:Th1 ratio. This has important ramifications for the future design of therapeutic strategies to prevent preterm labour and pregnancy loss (Figure 5). The percentage of CRTH2 positive decidual lymphocytes is far higher, accounting for $10.5 \%$ of $\mathrm{T}$ lymphocytes and $18 \%$ of CD4+ lymphocytes [44]. Exploring the effect of $15 \mathrm{dPGJ}_{2}$ on purified decidual $\mathrm{T}$ cells may give rise both Th1 suppression and Th2 cytokine promotion.

Immunomodulating therapies such as progesterone (for women at high risk of preterm labour) and intravenous Immunoglobulins (for women with recurrent miscarriage) are currently being used in a clinical context. Progesterone suppresses IFN- $\gamma$ production in peripheral blood mononuclear blood cells cultured with trophoblasts [54] and dydrogesterone suppresses both IFN- $\gamma$ and TNF$\alpha$ whilst increasing IL-4 in phytohaemagglutinin (PHA) stimulated PBMCs leading to a substantial Th1 to Th2 shift [55]. Immunoglobulins are capable of altering the Th1 :Th2 balance leading to a reduction in the CD4+IFN$\gamma^{+} / \mathrm{CD} 4^{+} \mathrm{IL}-4^{+}$lymphocyte ratio [56]. The endogenous protein, progesterone-induced blocking factor (PIBF), is capable of increasing the production of IL-4 and IL-10 in PBMC, but has no effect on the Th1 cytokines IFN- $\gamma$ and TNF- $\alpha$ [57].

$15 \mathrm{dPGJ}_{2}$ may show more promising immunomodulating effects for the prevention of preterm labour exploiting its ability to both suppress the Th1 cytokines with the added benefit of inhibiting NF- $\kappa \mathrm{B}$ activity. Preterm labour, particularly in the presence of chorioamnionitis, is associated with a shift towards the Th1 cytokine response [58]. PBMCs of women in preterm labour when stimulated with PMA produce significantly higher IFN- $\gamma$ compared to women who go on to deliver at term [59]. The presence of IFN- $\gamma$ in cervicovaginal fluid in the late second and early third trimesters has also been shown to be a risk factor for preterm labour in asymptomatic women [60]. Similarly, TNF- $\alpha$ is thought to be key cytokine involved in the initial trigger of biochemical events leading to infection-mediated preterm birth, for example, by causing prostaglandin $\mathrm{E}_{2}\left(\mathrm{PGE}_{2}\right)$ synthesis by intrauterine tissues which drive pathways leading to uterine contractility and cervical ripening [61-63]. While global changes in the PBMCs likely reflect important systemic inflammatory events, their sub-components (e.g., T cells, $\mathrm{B}$ cells, and monocytes) may play functionally independent 
roles at the maternal fetal interface. Future work using an in vivo model examining effects of $15 \mathrm{dPGJ}_{2}$ and CRTH2 agonists on Th1 and Th2 interleukins at local sites (e.g., decidua and myometrium) would allow us to extrapolate how immune cells influence nonimmune cell function.

Prophylactic administration of $15 \mathrm{dPGJ}_{2}$ to women at high risk of preterm birth may lead to the inability of infection to activate NF- $\kappa \mathrm{B}$ and thus preventing transcription of labour associated genes, and the inability to alter the Th1:Th2 bias to favour Th1, thus preventing the pro inflammatory detrimental environment of the fetus. Consideration for the route of administration should be supported by further studies of the potential local effect of $15 \mathrm{dPGJ}_{2}$ on interleukin production from the cervix, myometrium, and fetal membranes. The anti-inflammatory effect on NF$\kappa \mathrm{B}$ and the Th1 interleukins may not be replicated in the cervix, for example, which would serve as the least invasive route of administration of $15 \mathrm{dPGJ}_{2}$ in the form of a pessary. Absorption at the local level is also unlikely to provide systemic levels high enough to effect peripheral cytokine production, likewise, the effect of peripheral administration on the local maternal fetal interface is not guaranteed to result in a physiological effect. Nevertheless, this study shows promising potential for the future application of $15 \mathrm{dPGJ}_{2}$ as an immunomodulating therapy for infection-mediated preterm labour, and thus further studies examining its effect on gestational tissues should be pursued.

\section{Conclusion}

This study presents evidence that the Th1:Th2 balance is changed in pregnancy through Th1 suppression rather than Th2 promotion. We have also demonstrated the potential anti-inflammatory effects of $15 \mathrm{dPGJ}_{2}$ through the suppression of $\mathrm{NF}-\kappa \mathrm{B}$ and the Th1 proinflammatory cytokines IFN- $\gamma$ and TNF- $\alpha$. These properties may be of therapeutic benefit for the prevention of infection-mediated preterm labour and the reduction of inflammation induced neonatal morbidity, where an aberrant profile favouring the Th1 response is seen. Thus, future work in this area may be best directed toward designing therapeutic strategies aimed to manipulate the Th1 response during pregnancy as a rational strategy for the prevention of preterm labour and pregnancy loss/miscarriage.

\section{Conflict of Interests}

The authors report that no conflict of interests exist.

\section{Acknowledgment}

This study was funded by Wellbeing of Women.

\section{References}

[1] H. Honest, C. A. Forbes, K. H. Durée et al., "Screening to prevent spontaneous preterm birth: systematic reviews of accuracy and effectiveness literature with economic modelling," Health Technology Assessment, vol. 13, no. 43, pp. 1$627,2009$.

[2] R. L. Goldenberg, W. W. Andrews, and J. C. Hauth, "Choriodecidual infection and preterm birth," Nutrition Reviews, vol. 60, no. 5, pp. S19-S25, 2002.

[3] L. Sykes, D. A. MacIntyre, T. G. Teoh, and P. R. Bennett, "Targeting immune activation in the prevention of pre-term labour," European Obstetrics \& Gynaecology, vol. 6, no. 2, pp. 100-106, 2011.

[4] B. H. Yoon, R. Romero, J. S. Park et al., "Fetal exposure to an intra-amniotic inflammation and the development of cerebral palsy at the age of three years," American Journal of Obstetrics \& Gynecology, vol. 182, no. 3, pp. 675-681, 2000.

[5] E. T. Abrams and E. M. Miller, "The roles of the immune system in Women's reproduction: evolutionary constraints and life history trade-offs," American Journal of Physical Anthropology, vol. 146, supplement 53, pp. 134-154, 2011.

[6] T. R. Mosmann and S. Sad, "The expanding universe of T-cell subsets: Th1, Th2 and more," Immunology Today, vol. 17, no. 3, pp. 138-146, 1996.

[7] A. O'Garra and N. Arai, "The molecular basis of T helper 1 and T helper 2 cell differentiation," Trends in Cell Biology, vol. 10, no. 12, pp. 542-550, 2000.

[8] A. O'Garra, "Cytokines induce the development of functionally heterogeneous T helper cell subsets," Immunity, vol. 8, no. 3, pp. 275-283, 1998.

[9] K. M. Murphy, W. Ouyang, S. J. Szabo et al., "T helper differentiation proceeds through Stat1-dependent, Stat4-dependent and Stat4-independent phases," Current Topics in Microbiology and Immunology, vol. 238, pp. 23-26, 1999.

[10] T. G. Wegmann, H. Lin, L. Guilbert, and T. R. Mosmann, "Bidirectional cytokine interactions in the maternal-fetal relationship: is successful pregnancy a TH2 phenomenon?" Immunology Today, vol. 14, no. 7, pp. 353-356, 1993.

[11] R. Mattsson, R. Holmdahl, A. Scheynius, F. Bernadotte, A. Mattsson, and P. H. van der Meide, "Placental MHC class I antigen expression is induced in mice following in vivo treatment with recombinant interferon-gamma," Journal of Reproductive Immunology, vol. 19, no. 2, pp. 115-129, 1991.

[12] B. U. Tezabwala, P. M. Johnson, and R. C. Rees, "Inhibition of pregnancy viability in mice following IL-2 administration," Immunology, vol. 67, no. 1, pp. 115-119, 1989.

[13] G. Chaouat, A. A. Meliani, J. Martal et al., "IL-10 prevents naturally occuring fetal loss in the CBA $x$ DBA/2 mating combination, and local defect in IL-10 production in this abortion-prone combination is corrected by in vivo injection of IFN- $\tau$," Journal of Immunology, vol. 154, no. 9, pp. 42614268, 1995.

[14] R. Druckmann and M. A. Druckmann, "Progesterone and the immunology of pregnancy," Journal of Steroid Biochemistry and Molecular Biology, vol. 97, no. 5, pp. 389-396, 2005.

[15] H. Lin, T. R. Mosmann, L. Guilbert, S. Tuntipopipat, and T. G. Wegmann, "Synthesis of T helper 2-type cytokines at the maternal-fetal interface," Journal of Immunology, vol. 151, no. 9, pp. 4562-4573, 1993.

[16] M. Marzi, A. Vigano, D. Trabattoni et al., "Characterization of type 1 and type 2 cytokine production profile in physiologic and pathologic human pregnancy," Clinical and Experimental Immunology, vol. 106, no. 1, pp. 127-133, 1996.

[17] J. Tranchot-Diallo, G. Gras, F. Parnet-Mathieu et al., "Modulations of cytokine expression in pregnant women," American Journal of Reproductive Immunology, vol. 37, no. 3, pp. 215226, 1997. 
[18] M. D. Bates, S. Quenby, K. Takakuwa, P. M. Johnson, and G. S. Vince, "Aberrant cytokine production by peripheral blood mononuclear cells in recurrent pregnancy loss?" Human Reproduction, vol. 17, no. 9, pp. 2439-2444, 2002.

[19] S. Shimada, K. Iwabuchi, E. H. Kato et al., "No difference in natural-killer-T cell population, but $\mathrm{Th} 2 / \mathrm{Tc} 2$ predominance in peripheral blood of recurrent aborters," American Journal of Reproductive Immunology, vol. 50, no. 4, pp. 334-339, 2003.

[20] R. Raghupathy, M. Makhseed, R. Azizieh, A. Omu, M. Gupta, and R. Farhat, "Cytokine production by maternal lymphocytes during normal human pregnancy and in unexplained recurrent spontaneous abortion," Human Reproduction, vol. 15, no. 3, pp. 713-718, 2000.

[21] J. Trowsdale and A. G. Betz, "Mother's little helpers: mechanisms of maternal-fetal tolerance," Nature Immunology, vol. 7, no. 3, pp. 241-246, 2006.

[22] J. Szekeres-Bartho, A. Barakonyi, G. Par, B. Polgar, T. Palkovics, and L. Szereday, "Progesterone as an immunomodulatory molecule," International Immunopharmacology, vol. 1, no. 6, pp. 1037-1048, 2001.

[23] S. A. Huber, J. Kupperman, and M. K. Newell, "Estradiol prevents and testosterone promotes Fas-dependent apoptosis in $\mathrm{CD}^{+}$Th2 cells by altering Bcl 2 expression," Lupus, vol. 8, no. 5, pp. 384-387, 1999.

[24] L. Xue, S. L. Gyles, F. R. Wettey et al., "Prostaglandin D2 causes preferential induction of proinflammatory Th2 cytokine production through an action on chemoattractant receptor-like molecule expressed on Th2 cells," Journal of Immunology, vol. 175, no. 10, pp. 6531-6536, 2005.

[25] T. Michimata, H. Tsuda, M. Sakai et al., "Accumulation of CRTH2-positive T-helper 2 and T-cytotoxic 2 cells at implantation sites of human decidua in a prostaglandin D2mediated manner," Molecular Human Reproduction, vol. 8, no. 2, pp. 181-187, 2002.

[26] T. Shibata, M. Kondo, T. Osawa, N. Shibata, M. Kobayashi, and K. Uchida, "15-Deoxy $\Delta^{12,14}$-prostaglandin $\mathrm{J}_{2}$. A prostaglandin $\mathrm{D}_{2}$ metabolite generated during inflammatory processes," Journal of Biological Chemistry, vol. 277, no. 12, pp. 1045910466, 2002.

[27] K. Nagata and H. Hirai, "The second PGD2 receptor CRTH2: structure, properties, and functions in leukocytes," Prostaglandins Leukotrienes and Essential Fatty Acids, vol. 69, no. 2-3, pp. 169-177, 2003.

[28] T. M. Lindström and P. R. Bennett, "15-Deoxy- $\Delta^{12,14}$ prostaglandin $\mathrm{J}_{2}$ inhibits interleukin- $\beta$-induced nuclear factor- $\kappa \mathrm{B}$ in human amnion and myometrial cells: mechanisms and implications," Journal of Clinical Endocrinology and Metabolism, vol. 90, no. 6, pp. 3534-3543, 2005.

[29] G. Pirianov, S. N. Waddington, T. M. Lindström, V. Terzidou, H. Mehmet, and P. R. Bennett, "The cyclopentenone 15-deoxy- $\Delta^{12,14}$-prostaglandin $\mathrm{J}_{2}$ delays lipopolysaccharideinduced preterm delivery and reduces mortality in the newborn mouse," Endocrinology, vol. 150, no. 2, pp. 699-706, 2009.

[30] S. A. McCracken, E. Gallery, and J. M. Morris, "Pregnancyspecific down-regulation of NF- $\kappa \mathrm{B}$ expression in T cells in humans is essential for the maintenance of the cytokine profile required for pregnancy success," Journal of Immunology, vol. 172, no. 7, pp. 4583-4591, 2004.

[31] K. A. Hadfield, S. A. McCracken, A. W. Ashton, T. G. Nguyen, and J. M. Morris, "Regulated suppression of NF$\kappa \mathrm{B}$ throughout pregnancy maintains a favourable cytokine environment necessary for pregnancy success," Journal of Reproductive Immunology, vol. 89, no. 1, pp. 1-9, 2011.
[32] P. B. Medawar, "Some immunological and endocrinological problems raised by the evolution of viviparity in vertebrates," Symposia of the Society for Experimental Biology, vol. 7, pp. 320-338, 1953.

[33] S. Zourbas, S. Dubanchet, J. Martal, and G. Chaouat, "Localization of pro-inflammatory (IL-12, IL-15) and antiinflammatory (IL-11, IL-13) cytokines at the foetomaternal interface during murine pregnancy," Clinical and Experimental Immunology, vol. 126, no. 3, pp. 519-528, 2001.

[34] L. Keski-Nisula, M. R. Hirvonen, M. Roponen, S. Heinonen, and J. Pekkanen, "Maternal and neonatal IL-4 and IFNgamma production at delivery and 3 months after birth," Journal of Reproductive Immunology, vol. 60, no. 1, pp. 25-33, 2003.

[35] G. Reinhard, A. Noll, H. Schlebusch, P. Mallmann, and A. V. Ruecker, "Shifts in the TH1/TH2 balance during human pregnancy correlate with apoptotic changes," Biochemical and Biophysical Research Communications, vol. 245, no. 3, pp. 933938, 1998.

[36] V. C. Allport, D. Pieber, D. M. Slater, R. Newton, J. O. White, and P. R. Bennett, "Human labour is associated with nuclear factor- $\kappa \mathrm{B}$ activity which mediates cyclo-oxygenase- 2 expression and is involved with the 'functional progesterone withdrawal'” Molecular Human Reproduction, vol. 7, no. 6, pp. 581-586, 2001.

[37] N. R. Chapman, G. N. Europe-Finner, and S. C. Robson, "Expression and deoxyribonucleic acid-binding activity of the nuclear factor $\kappa \mathrm{B}$ family in the human myometrium during pregnancy and labor," Journal of Clinical Endocrinology and Metabolism, vol. 89, no. 11, pp. 5683-5693, 2004.

[38] G. L. Veith and G. E. Rice, "Interferon gamma expression during human pregnancy and in association with labour," Gynecologic and Obstetric Investigation, vol. 48, no. 3, pp. 163$167,1999$.

[39] A. Young, A. J. Thomson, M. Ledingham, F. Jordan, I. A. Greer, and J. E. Norman, "Immunolocalization of proinflammatory cytokines in myometrium, cervix, and fetal membranes during human parturition at term," Biology of Reproduction, vol. 66, no. 2, pp. 445-449, 2002.

[40] S. J. Fortunato, R. P. Menon, K. F. Swan, and R. Menon, "Inflammatory cytokine (interleukins 1, 6, and 8 and tumor necrosis factor- $\alpha$ ) release from cultured human fetal membranes in response to endotoxic lipopolysaccharide mirrors amniotic fluid concentrations," American Journal of Obstetrics \& Gynecology, vol. 174, no. 6, pp. 1855-1862, 1996, discussion 1861-1862.

[41] L. Matthiesen, C. Ekerfelt, G. Berg, and J. Ernerudh, "Increased numbers of circulating interferon- $\gamma$ - and interleukin-4-secreting cells during normal pregnancy," American Journal of Reproductive Immunology, vol. 39, no. 6, pp. 362-367, 1998.

[42] L. Matthiesen, M. Khademi, C. Ekerfelt et al., "In-situ detection of both inflammatory and anti-inflammatory cytokines in resting peripheral blood mononuclear cells during pregnancy," Journal of Reproductive Immunology, vol. 58, no. 1, pp. 49-59, 2003.

[43] K. Nagata, K. Tanaka, K. Ogawa et al., "Selective expression of a novel surface molecule by human Th2 cells in vivo," Journal of Immunology, vol. 162, no. 3, pp. 1278-1286, 1999.

[44] H. Tsuda, T. Michimata, M. Sakai, K. Nagata, M. Nakamura, and S. Saito, "A novel surface molecule of Th2- and Tc2-type cells, CRTH2 expression on human peripheral and decidual $\mathrm{CD}^{+}$and $\mathrm{CD}^{+} \mathrm{T}$ cells during the early stage of pregnancy," 
Clinical and Experimental Immunology, vol. 123, no. 1, pp. 105-111, 2001.

[45] R. J. A. Helliwell, J. A. Keelan, K. W. Marvin et al., "Gestational age-dependent up-regulation of prostaglandin D synthase (PGDS) and production of PGDS-derived antiinflammatory prostaglandins in human placenta," Journal of Clinical Endocrinology and Metabolism, vol. 91, no. 2, pp. 597-606, 2006.

[46] A. Jawerbaum, E. Capobianco, C. Pustovrh et al., "Influence of peroxisome proliferator-activated receptor $\gamma$ activation by its endogenous ligand 15 -deoxy $\Delta^{12,14}$ prostaglandin $\mathrm{J}_{2}$ on nitric oxide production in term placental tissues from diabetic women," Molecular Human Reproduction, vol. 10, no. 9, pp. 671-676, 2004.

[47] M. Fukushima, "Prostaglandin $\mathrm{J}_{2}$-anti-tumour and antiviral activities and the mechanisms involved," Eicosanoids, vol. 3, no. 4, pp. 189-199, 1990.

[48] S. W. Chung, B. Y. Kang, and T. S. Kim, "Inhibition of interleukin-4 production in $\mathrm{CD}^{+} \mathrm{T}$ cells by peroxisome proliferator-activated receptor- $\gamma$ (PPAR- $\gamma$ ) ligands: involvement of physical association between PPAR- $\gamma$ and the nuclear factor of activated T cells transcription factor," Molecular Pharmacology, vol. 64, no. 5, pp. 1169-1179, 2003.

[49] M. Ricote, A. C. Li, T. M. Willson, C. J. Kelly, and C. K. Glass, "The peroxisome proliferator-activated receptor- $\gamma$ is a negative regulator of macrophage activation," Nature, vol. 391, no. 6662, pp. 79-82, 1998.

[50] S. A. McCracken, C. L. Drury, H. S. Lee, and J. M. Morris, "Pregnancy is associated with suppression of the nuclear factor $\kappa \mathrm{B} / \mathrm{I} \kappa \mathrm{B}$ activation pathway in peripheral blood mononuclear cells," Journal of Reproductive Immunology, vol. 58, no. 1, pp. 27-47, 2003.

[51] E. Cernuda-Morollón, E. Pineda-Molina, F. Javier Cañada, and D. Pérez-Sala, "15-Deoxy- $\Delta^{12,14}$-prostaglandin $\mathrm{J}_{2}$ inhibition of NF- $\kappa$ B-DNA binding through covalent modification of the p50 subunit," Journal of Biological Chemistry, vol. 276, no. 38, pp. 35530-35536, 2001.

[52] A. Rossi, P. Kapahi, G. Natoli et al., "Anti-inflammatory cyclopentenone prostaglandins are direct inhibitors of $\mathrm{I} \kappa \mathrm{B}$ kinase," Nature, vol. 403, no. 6765, pp. 103-108, 2000.

[53] D. S. Straus, G. Pascual, M. Li et al., "15-deoxy- $\Delta^{12,14}$ prostaglandin $\mathrm{J}_{2}$ inhibits multiple steps in the NF- $\kappa \mathrm{B}$ signaling pathway," Proceedings of the National Academy of Sciences of the United States of America, vol. 97, no. 9, pp. 4844-4849, 2000.

[54] B. C. Choi, K. Polgar, L. Xiao, and J. A. Hill, "Progesterone inhibits in-vitro embryotoxic Th1 cytokine production to trophoblast in women with recurrent pregnancy loss," Human Reproduction, vol. 15, supplement 1, pp. 46-59, 2000.

[55] R. Raghupathy, E. Al Mutawa, M. Makhseed, F. Azizieh, and J. Szekeres-Bartho, "Modulation of cytokine production by dydrogesterone in lymphocytes from women with recurrent miscarriage," BJOG, vol. 112, no. 8, pp. 1096-1101, 2005.

[56] H. Yamada, M. Morikawa, I. Furuta et al., "Intravenous immunoglobulin treatment in women with recurrent abortions: increased cytokine levels and reduced Th1/Th2 lymphocyte ratio in peripheral blood," American Journal of Reproductive Immunology, vol. 49, no. 2, pp. 84-89, 2003.

[57] R. Raghupathy, E. Al-Mutawa, M. Al-Azemi, M. Makhseed, F. Azizieh, and J. Szekeres-Bartho, "Progesterone-induced blocking factor (PIBF) modulates cytokine production by lymphocytes from women with recurrent miscarriage or preterm delivery," Journal of Reproductive Immunology, vol. 80, no. 1-2, pp. 91-99, 2009.
[58] J. R. Wilczynski, “Th1/Th2 cytokines balance-yin and yang of reproductive immunology," European Journal of Obstetrics \& Gynecology and Reproductive Biology, vol. 122, no. 2, pp. 136-143, 2005.

[59] M. Makhseed, R. Raghupathy, S. El-Shazly, F. Azizieh, J. A. AlHarmi, and M. M. K. Al-Azemi, "Pro-inflammatory maternal cytokine profile in preterm delivery," American Journal of Reproductive Immunology, vol. 49, no. 5, pp. 308-318, 2003.

[60] F. Ni Chuileannain and S. Brennecke, "Prediction of preterm labour in multiple pregnancies," Bailliere's Clinical Obstetrics and Gynaecology, vol. 12, no. 1, pp. 53-66, 1998.

[61] H. A. Alexander, S. R. Sooranna, L. Myatt, and M. R. Johnson, "Myometrial tumor necrosis factor- $\alpha$ receptors increase with gestation and labor and modulate gene expression through mitogen-activated kinase and nuclear factor- $\kappa \mathrm{B}$," Reproductive Sciences, vol. 19, no. 1, pp. 43-54, 2012.

[62] R. Romero, D. T. Brody, E. Oyarzun et al., "Infection and labor. III. Interleukin-1: a signal for the onset of parturition," American Journal of Obstetrics \& Gynecology, vol. 160, no. 5, pp. 1117-1123, 1989.

[63] D. W. Sadowsky, K. M. Adams, M. G. Gravett, S. S. Witkin, and M. J. Novy, "Preterm labor is induced by intraamniotic infusions of interleukin- $1 \beta$ and tumor necrosis factor- $\alpha$ but not by interleukin- 6 or interleukin- 8 in a nonhuman primate model," American Journal of Obstetrics \& Gynecology, vol. 195, no. 6, pp. 1578-1589, 2006. 


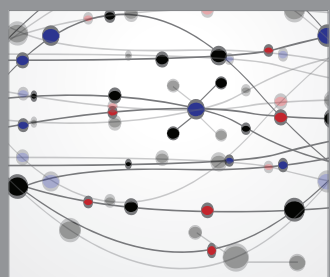

The Scientific World Journal
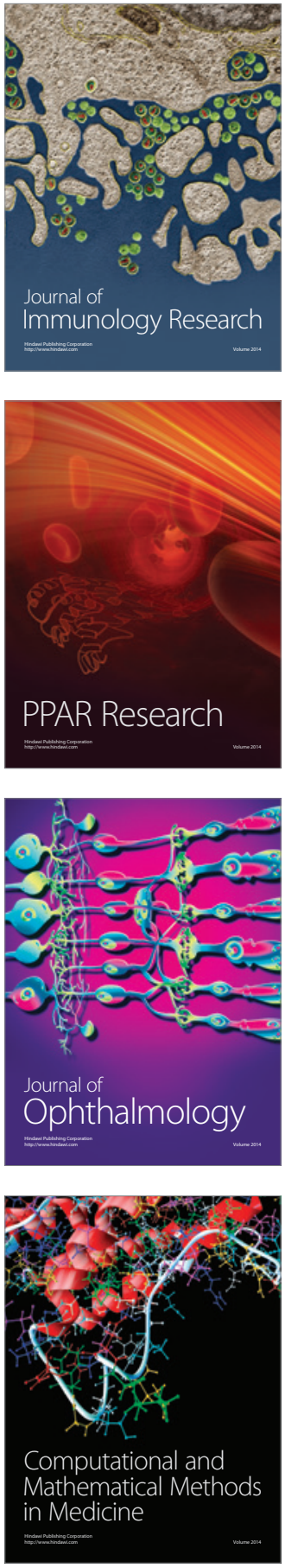

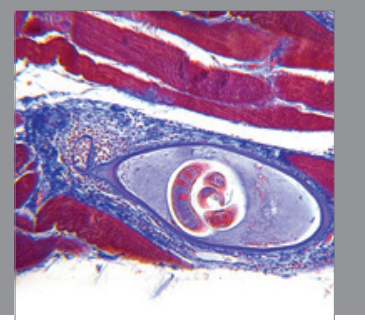

Gastroenterology

Research and Practice
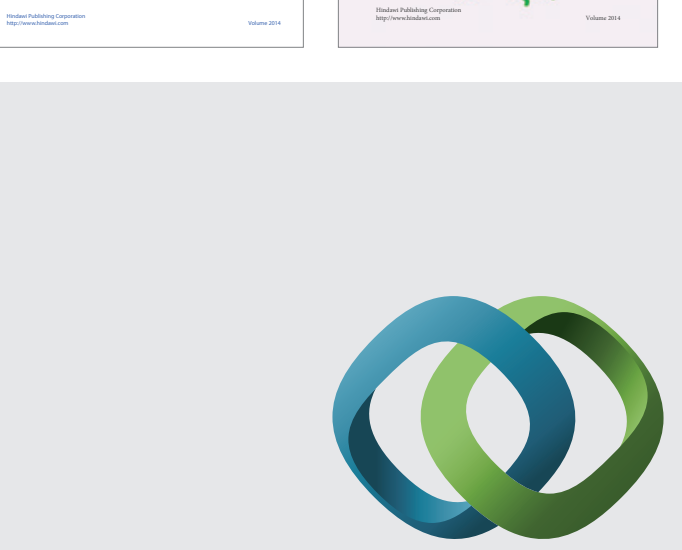

\section{Hindawi}

Submit your manuscripts at

http://www.hindawi.com
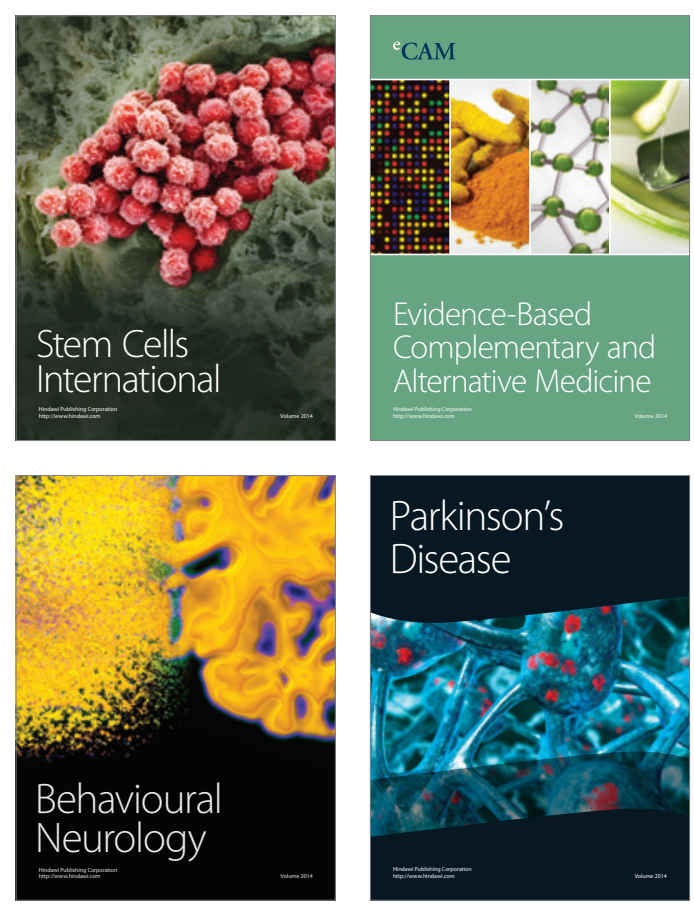

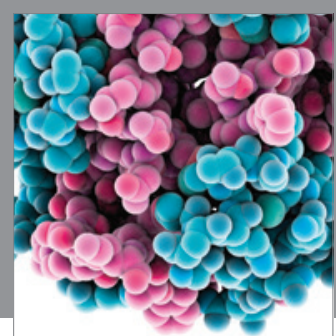

Journal of
Diabetes Research

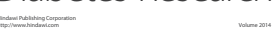

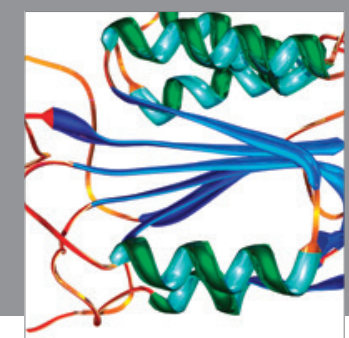

Disease Markers
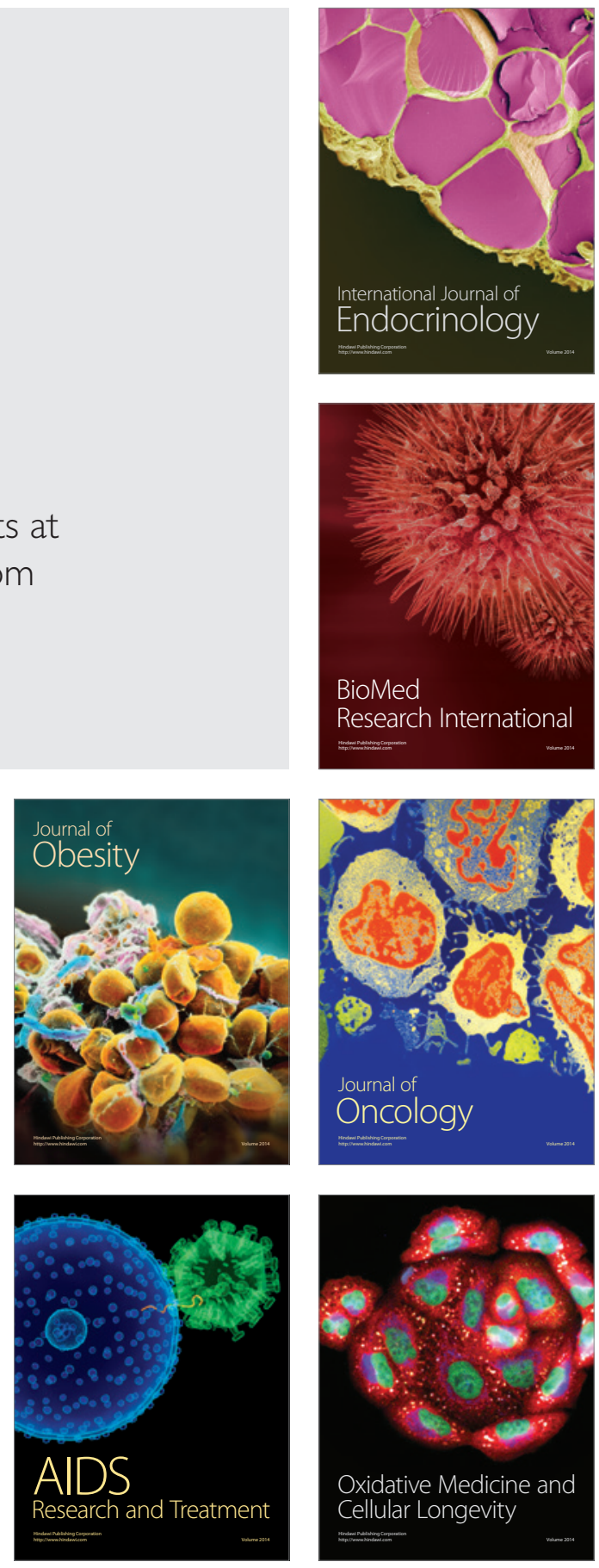